\title{
The assessment of coronary heart disease risk factors correlated with demographic and social data in post-coronary intervention patients in Polish population
}

\author{
Monika Budnik, Grzegorz Opolski \\ $1^{\text {st }}$ Department of Cardiology, Medical University of Warsaw, Warsaw, Poland
}

\begin{abstract}
Background: Cardiovascular diseases are the main cause of death in Europe, accounting for over 4 million deaths each year. Smoking cigarettes, an unhealthy diet and no physical activity constitute important risk factors. Educational program was conducted among patients after coronary angioplasty. Data on patients' knowledge of risk factors of coronary heart disease, recommended behavior, secondary prevention methods, and side effects were collected and analyzed in conjunction with demographic and social factors. One questionnaire included details about 20 patients. The questionnaire included demographic data (gender, education, place of residence), epidemiological (height, weight, waist size), interview on coronary heart disease risk factors, medications and side effects.
\end{abstract}

Methods: The educational program involved 19,316 patients above 18 years old after percutaneous coronary intervention (PCI). The basic tool was a standardized questionnaire consisting of visit forms.

Results: Despite PCI, $20.5 \%$ of patients smoke cigarettes, more often men, younger, less educated. $35.7 \%$ of patients believe that limiting physical activity after successful coronary intervention is beneficial - more often older, lower educated, with higher body mass index, from smaller towns. $85 \%$ of patients (mainly women, younger, higher-educated, coming from bigger cities) claim to be aware which products are beneficial for the cardiovascular system and which have a negative influence. $8 \%$ of patients after PCI do not control their blood pressure at all - more often men, younger people with lower level of education and coming from smaller towns. $44 \%$ of patients happened to forget to take or ran out of some medications - more often those with lower level of education.

Conclusions: It is essential to implement to clinical practice educational programs for postcoronary intervention patients. These patients are at highest risk of having cardiovascular events. Educational programs should be addressed to all post-coronary intervention patients, especially to those coming from small towns. A limitation of the survey was that patients were not divided into acute coronary syndrome patients and stable coronary heart disease ones. It was not specified what time after the coronary intervention the patients were included into the research. (Cardiol J 2015; 22, 3: 276-284)

Key words: coronary heart disease risk factors, secondary prevention, patients after percutaneous coronary intervention, lifestyle, educational program

Address for correspondence: Monika Budnik, MD, $1^{\text {st }}$ Department of Cardiology, Medical University of Warsaw, ul. Banacha 1a, 02-097 Warszawa, Poland, e-mail: moni.budnik@gmail.com 


\section{Introduction}

Cardiovascular diseases (CVD) are the main cause of death in Europe, accounting for over 4 million deaths each year. Under half of all deaths from CVD in both men and women are from coronary heart disease (CHD). CHD by itself is the single most common cause of death in Europe: accounting for 1.8 million deaths in Europe each year. Over 1 in 5 women (22\%) and 1 in 5 men (20\%) die from CHD [1]. Smoking cigarettes, an unhealthy diet and no physical activity constitute important CHD risk factors [2]. There is a lot of scientific evidence that modifying a lifestyle, eliminating risk factors and taking appropriate medications improve survival in CHD patients [3]. Findings of the research show that reduction of cardiac mortality by $50-75 \%$ can be attributed to reducing the incidence of main risk factors such as smoking cigarettes, hypercholesterolemia, increased blood pressure [4,5]. Unfortunately, compliance with the recommendations on secondary prevention is not satisfactory [6].

\section{Methods}

The educational program involved 19,316 patients above 18 years old after coronary intervention. The program covered all Poland. The basic tool used in the program was a standardized questionnaire consisting of visit forms. One questionnaire included details about 20 patients. The research was carried out in 2010-2011 on a cyclical basis. One cycle lasted 90 days and covered consecutive patients who went to see a doctor and met the inclusion criteria. The questionnaire included demographic data (gender, education, place of residence), epidemiological (height, weight, waist size), interview on CHD risk factors, medications, and side effects. At the end of the appointment, having completed the questionnaire, the patients were given educational materials on ischemic heart disease, risk factors, recommendations on lifestyle and taking medications. The written consent was not obtained from the local Ethics Committee because of the lack of any intervention. The patients were asked to fill a questionnaire only (Table 1).

\section{Statistical analysis}

In order to compare the change of a given variable, the Student's t-test was applied for two independent samples or its non-parametric equivalent - the Wilcoxon test. For analyzing the differences between more than one dependent group ANOVA
Table 1. Patients' demographic and sociological data.

\begin{tabular}{lc}
\hline Total number & 19,316 \\
Women & $7,576(39 \%)$ \\
Age [years] & $62.36 \pm 10.07$ \\
Height $[\mathrm{cm}]$ & $170.32 \pm 8.61$ \\
Weight $[\mathrm{kg}]$ & $83.08 \pm 12.29$ \\
Waist size [cm] & $92.92 \pm 27.73$ \\
Body mass index $\left[\mathrm{kg} / \mathrm{m}^{2}\right]$ & $28.63 \pm 3.8$ \\
Education: & \\
Primary & $3,933(20.4 \%)$ \\
Secondary & $9,208(47.7 \%)$ \\
Incomplete higher & $2,483(12.9 \%)$ \\
$\quad$ University education & $2,985(15.5 \%)$ \\
Size of place of residence: & \\
Village & $3,865(20 \%)$ \\
Town up to 100 thousand & $6,878(36 \%)$ \\
City above 100 thousand & $4,063(21 \%)$ \\
City above 500 thousand & $3,742(19 \%)$ \\
\hline
\end{tabular}

was applied or its non-parametric equivalent the Friedman test. For analyzing the differences between independent groups, the t-Student test was applied for independent groups or its nonparametric equivalent - the Mann-Whitney U test. For analyzing the connection between the variables the Pearson's $r$ test was applied or its non-parametric equivalent - the Spearman's $\rho$ test or $\chi^{2}$ for variables on nominal scale. Ninety-nine percent confidence interval was selected. Casewise deletion of missing data.

\section{Results}

We analyzed the most important risk factors for CHD: smoking, physical inactivity, dyslipidemia, poor diet, and high blood pressure. We also determined the prevalence of symptoms of restenosis, compliance in taking medication, the presence of adverse events and the need to undergo surgery.

Of the 19,316 patients, $61 \%$ were male. The mean age was 62.36 years. The mean body mass index (BMI) was $28.6 \mathrm{~kg} / \mathrm{m}^{2} ; 70 \%$ of patients had family history of CVD; $59.7 \%$ of patients used to smoke cigarettes; $52.3 \%$ of women, and $28.7 \%$ of men were obese.

\section{Smoking cigarettes}

Fifty-nine point seven percent of patients who underwent percutaneous coronary intervention (PCI) used to smoke cigarettes. When the question- 
Table 2. Smoking in the study group.

\begin{tabular}{|c|c|c|c|c|c|c|c|c|}
\hline & & & \multicolumn{2}{|c|}{ Current smoking } & \multirow[t]{2}{*}{$\mathbf{P}$} & \multicolumn{2}{|c|}{ Former smoking } & \multirow[t]{2}{*}{$\mathbf{P}$} \\
\hline & & & No & Yes & & No & Yes & \\
\hline \multirow[t]{4}{*}{ Gender: } & Female & Numbers & 6,284 & 1,129 & & 4,234 & 3,236 & \\
\hline & & Expected numbers & $5,859.7$ & $1,553.3$ & \multirow{2}{*}{$<0.001$} & $2,926.9$ & $4,543.1$ & \multirow{2}{*}{$<0.001$} \\
\hline & \multirow[t]{2}{*}{ Male } & Numbers & 8,564 & 2,807 & & 3,167 & 8,252 & \\
\hline & & Expected numbers & $8,988.3$ & $2,382.7$ & & $4,474.1$ & $6,944.9$ & \\
\hline Age [ye & & & 63.8 & 59.8 & \multirow[t]{2}{*}{$<0.001$} & 64.01 & 61.34 & \multirow[t]{2}{*}{$<0.001$} \\
\hline \multirow{4}{*}{\multicolumn{2}{|c|}{ Place of residence size: }} & Village & 2,979 & 797 & & 1,721 & 2,086 & \\
\hline & & City $<100,000$ & 5,346 & 1,407 & \multirow{3}{*}{0.581} & 2,603 & 4,166 & \multirow{3}{*}{$<0.001$} \\
\hline & & City $100,000-500,000$ & 3,116 & 849 & & 1,589 & 2,417 & \\
\hline & & City > 500,000 & 2,927 & 743 & & 1,255 & 2,429 & \\
\hline \multirow{4}{*}{\multicolumn{2}{|c|}{ Education }} & Primary & 2,959 & 879 & & 1,665 & 2,201 & \multirow{4}{*}{$<0.001$} \\
\hline & & Secondary & 7,160 & 1,859 & \multirow{3}{*}{$<0.001$} & 3,488 & 5,583 & \\
\hline & & Incomplete higher & 1,921 & 525 & & 896 & 1,561 & \\
\hline & & University education & 2,390 & 543 & & 1,123 & 1,824 & \\
\hline
\end{tabular}

naire was being carried out (after PCI) the smokers accounted for $20.5 \%$ of patients. Men more often used to smoke cigarettes than women and they also more often continued to smoke $(\mathrm{p}<0.001)$. Men also had higher number of pack years (22.27 \pm \pm 14.12 compared with $16.04 \pm 14.066$ ).

Patients who continued to smoke were younger than those who stopped smoking $(59.8 \pm 10.17$ compared with $63.01 \pm 9.95)$. Fifty-seven point nine percent of patients were exposed to cigarette smoke in their direct environment (home, work). People who used to smoke came from bigger cities $(\mathrm{p}<0.001)$. There was, however, no correlation between the size of the place of residence and the continuation of smoking. There was no relationship between pack years and the size of place of residence. People who stopped smoking were better educated $(\mathrm{p}<0.001)$ (Table 2$)$.

\section{Physical activity}

Thirty-five point seven percent of patients, both men and women, believed that limiting physical activity after PCI was beneficial. These respondents were older, had worse level of education and higher BMI and they came from smaller towns $(\mathrm{p}<0.001)$.

More than one third of patients (34.2\%) were afraid of taking moderate physical activity, such as walking, running, cycling, or Nordic walking. That group of patients more often includes women, elderly people with worse level of education and higher BMI, coming from smaller towns $(\mathrm{p}<0.001)$.
Sixty-eight point six percent of patients of both sexes expected to lose body weight after taking physical activity. That group usually consisted of younger people with higher education and higher BMI $(\mathrm{p}<0.001)$ (Table 3).

\section{Dyslipidemia}

Eighty-seven point four percent of patients had their cholesterol and its fractions tested after PCI; $83.1 \%$ of them were informed what level of lipids is correct. More often it referred to people who lived in bigger cities $(\mathrm{p}<0.001)$.

\section{Diet}

Eighty-five percent of patients claimed to be aware which products were beneficial for the cardiovascular system (CVS) and which had a negative influence. Seventy-seven point seven percent of people knew which fats, types of bread or spices had a positive impact on the CVS. These questions were positively answered more often by women, younger people, better educated, and coming from bigger cities; $37.2 \%$ of patients who underwent PCI did not eat at regular times. That group consisted more often of men, younger people, lower educated, with higher BMI ( $\mathrm{p}<0.001)$. Thirty-four point four percent of people believed that drinking 1-2 cups of coffee a day is harmful for the CVS. That group comprised more often women, elderly people, lower educated and with higher BMI, residing in smaller cities $(\mathrm{p}<0.001)$. 
Table 3. Physical activity in the study group.

\begin{tabular}{|c|c|c|c|c|c|}
\hline & & $\mathbf{N}$ & Medial & Standard deviation & $\mathbf{P}$ \\
\hline \multicolumn{6}{|c|}{$\begin{array}{l}\text { Do you think that the limitation of physical activity after } \\
\text { successful coronary angioplasty is advisable/beneficial? }\end{array}$} \\
\hline Age & $\begin{array}{l}\text { No } \\
\text { Yes }\end{array}$ & $\begin{array}{c}12,256 \\
6,847\end{array}$ & $\begin{array}{l}61.85 \\
63.26\end{array}$ & $\begin{array}{l}9.881 \\
10.33\end{array}$ & $<0.001$ \\
\hline $\begin{array}{l}\text { Education } \\
(1=\text { primary, } 4=\text { higher })\end{array}$ & $\begin{array}{l}\text { No } \\
\text { Yes }\end{array}$ & $\begin{array}{c}11,900 \\
6,656\end{array}$ & $\begin{array}{l}2.31 \\
2.13\end{array}$ & $\begin{array}{l}0.972 \\
0.937\end{array}$ & $<0.001$ \\
\hline Body mass index & $\begin{array}{l}\text { No } \\
\text { Yes }\end{array}$ & $\begin{array}{c}11,742 \\
6,534\end{array}$ & $\begin{array}{l}28.49 \\
28.89\end{array}$ & $\begin{array}{l}3.69 \\
3.99\end{array}$ & $<0.001$ \\
\hline $\begin{array}{l}\text { Place of residence } \\
(1=\text { village, } 4=\text { city }>500,000)\end{array}$ & $\begin{array}{l}\text { No } \\
\text { Yes }\end{array}$ & $\begin{array}{c}11,851 \\
6,642\end{array}$ & $\begin{array}{l}2.43 \\
2.38\end{array}$ & $\begin{array}{l}1.023 \\
1.044\end{array}$ & $<0.001$ \\
\hline \multicolumn{6}{|c|}{$\begin{array}{l}\text { Are you afraid of performing moderate physical activity } \\
\text { (walking, running, cycling, Nordic walking)? }\end{array}$} \\
\hline Age & $\begin{array}{l}\text { No } \\
\text { Yes }\end{array}$ & $\begin{array}{c}12,536 \\
6,575\end{array}$ & $\begin{array}{l}61.57 \\
63.89\end{array}$ & $\begin{array}{c}9.81 \\
10.39\end{array}$ & $<0.001$ \\
\hline $\begin{array}{l}\text { Education } \\
(1=\text { primary, } 4=\text { higher })\end{array}$ & $\begin{array}{l}\text { No } \\
\text { Yes }\end{array}$ & $\begin{array}{c}12,186 \\
6,377\end{array}$ & $\begin{array}{l}2.31 \\
2.12\end{array}$ & $\begin{array}{l}0.97 \\
0.94\end{array}$ & $<0.001$ \\
\hline Body mass index & $\begin{array}{l}\text { No } \\
\text { Yes }\end{array}$ & $\begin{array}{c}12,062 \\
6,223\end{array}$ & $\begin{array}{l}28.45 \\
28.99\end{array}$ & $\begin{array}{l}3.65 \\
4.06\end{array}$ & $<0.001$ \\
\hline $\begin{array}{l}\text { Place of residence } \\
(1=\text { village, } 4=\text { city }>500,000)\end{array}$ & $\begin{array}{l}\text { No } \\
\text { Yes }\end{array}$ & $\begin{array}{c}12,117 \\
6,384\end{array}$ & $\begin{array}{l}2.44 \\
2.36\end{array}$ & $\begin{array}{l}1.03 \\
1.03\end{array}$ & $<0.001$ \\
\hline \multicolumn{6}{|c|}{$\begin{array}{l}\text { Do you expect weight loss after use of moderate } \\
\text { physical exercise? }\end{array}$} \\
\hline Age & $\begin{array}{l}\text { No } \\
\text { Yes }\end{array}$ & $\begin{array}{c}5,948 \\
13,154\end{array}$ & $\begin{array}{l}63.26 \\
61.95\end{array}$ & $\begin{array}{c}10.61 \\
9.79\end{array}$ & $<0.001$ \\
\hline $\begin{array}{l}\text { Education } \\
(1=\text { primary, } 4=\text { higher })\end{array}$ & $\begin{array}{l}\text { No } \\
\text { Yes }\end{array}$ & $\begin{array}{c}5,764 \\
12,791\end{array}$ & $\begin{array}{l}2.18 \\
2.27\end{array}$ & $\begin{array}{l}0.97 \\
0.96\end{array}$ & $<0.001$ \\
\hline Body mass index & $\begin{array}{l}\text { No } \\
\text { Yes }\end{array}$ & $\begin{array}{c}5,758 \\
12,518\end{array}$ & $\begin{array}{l}28.17 \\
28.84\end{array}$ & $\begin{array}{l}3.86 \\
3.76\end{array}$ & $<0.001$ \\
\hline $\begin{array}{l}\text { Place of residence } \\
(1=\text { village, } 4=\text { city }>500,000)\end{array}$ & $\begin{array}{l}\text { No } \\
\text { Yes }\end{array}$ & $\begin{array}{c}5,759 \\
12,732\end{array}$ & $\begin{array}{l}2.38 \\
2.43\end{array}$ & $\begin{array}{l}1.02 \\
1.04\end{array}$ & $<0.001$ \\
\hline
\end{tabular}

Thirty-one point one percent of patients believed that alcohol consumption had a positive impact on the CVS (the survey did not specify the amount of alcohol) - more often men, younger people, better educated, living in bigger cities; $29.7 \%$ of people were being persuaded to drink alcohol for either medical or preventive purposes (the amount of alcohol was not precisely given) most often men, younger people, better educated, living in bigger cities $(\mathrm{p}<0.001)$. Twenty-six point nine percent of people after PCI declared that dietary recommendations did not make them change their eating habits - more often men, the elderly, lower educated people with higher BMI, living in smaller towns $(\mathrm{p}<0.001)$ (Table 4$)$.

\section{Hypertension}

Eight percent of patients after PCI did not control their blood pressure (BP) at all. That group consisted more often of men, younger people with lower level of education and coming from smaller towns $(\mathrm{p}<0.001)$. Other patients controlled their $\mathrm{BP}$ at least once a day. Three percent of patients, more often coming from bigger cities, believed that BP values above $140 / 90 \mathrm{~mm} \mathrm{Hg}$ were acceptable and $9 \%$ of patients declared that the correct values are these that make them feel well - more often elderly people with lower level of education and coming from smaller towns; $40.8 \%$ of patients had to take additional medications due to high values of $\mathrm{BP}$.

\section{Restenosis}

Thirty-four point eight percent of patients happened to have chest pains; $65 \%$ declared that they could distinguish coronary pains from other pains - for example bone pains, spine pains, indigestion, heartburn; $27.6 \%$ of patients happened to 


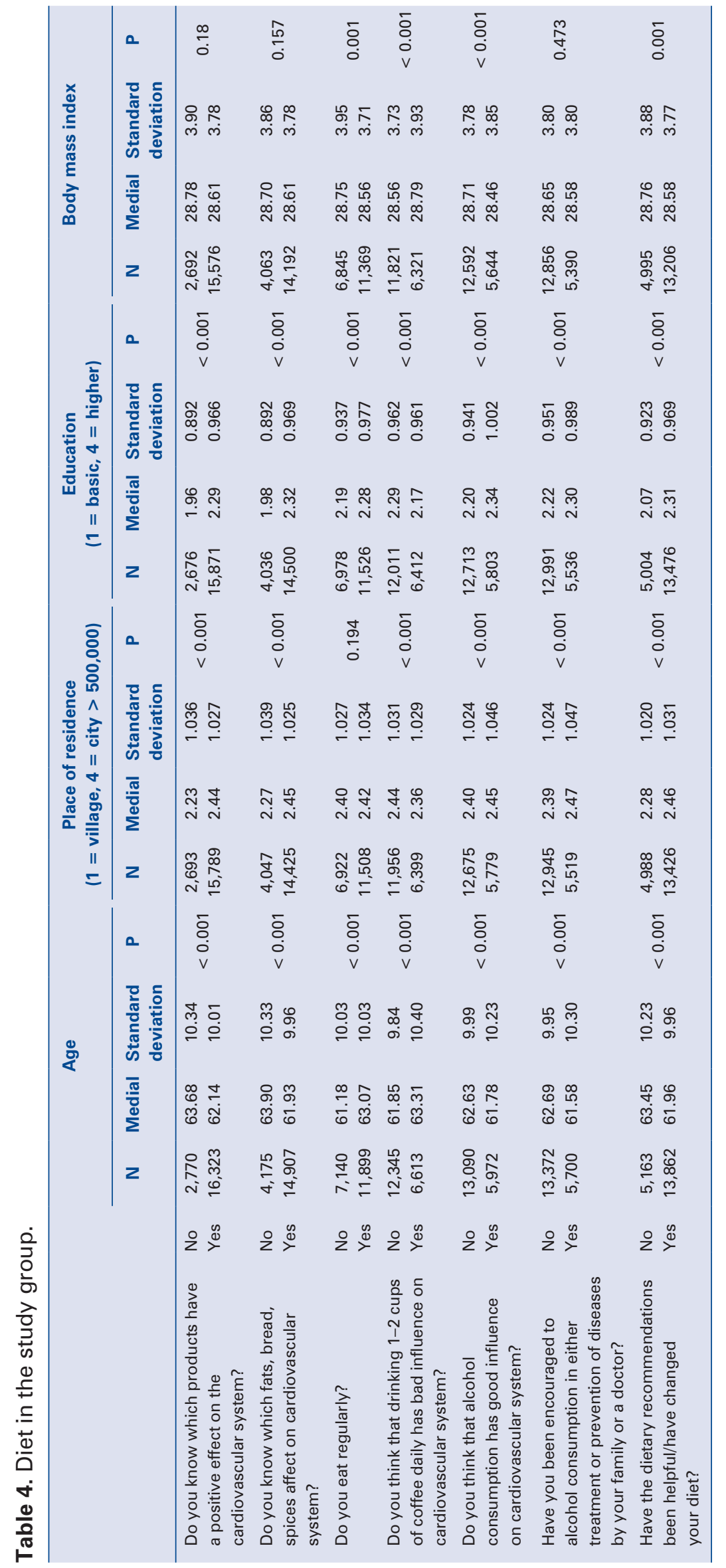




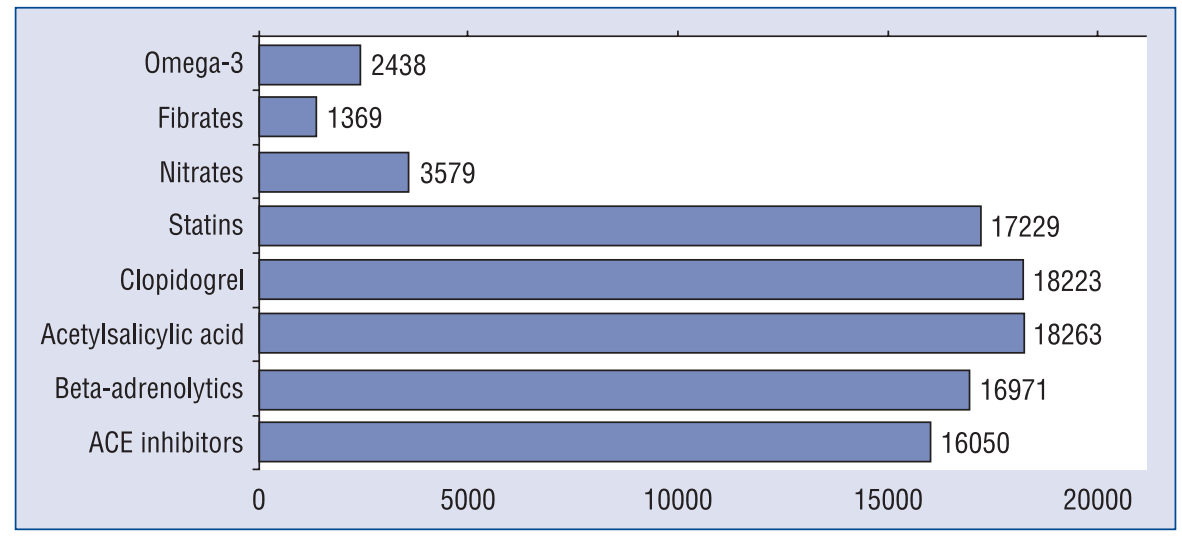

Figure 1. Medication after percutaneous coronary intervention; ACE — angiotensin converting enzyme.

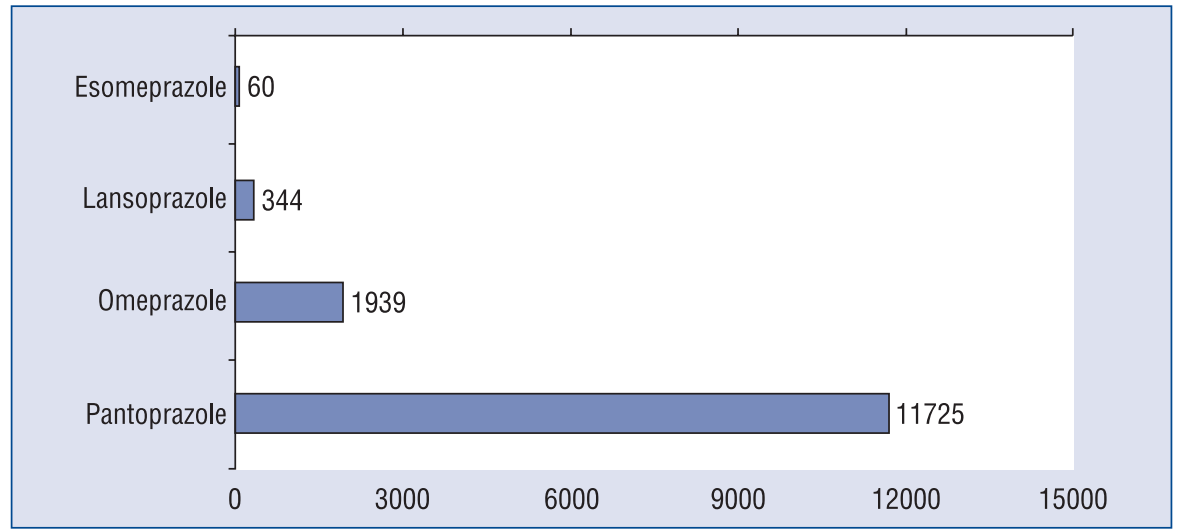

Figure 2. Proton pump inhibitors after percutaneous coronary intervention.

have dyspnea after climbing the second floor; $11 \%$ had difficulty taking basic everyday activities. This refers more often to people with higher BMI and current smokers $(\mathrm{p}<0.001)$.

\section{Minor surgeries/operations}

Fourteen point two percent of patients planned to undergo a dentist, ophthalmologic, gastroenterological examination or a surgery. Thirteen point eight percent of patients, due to the fact that they had undergone PCI, were offered to reschedule the planned operation.

\section{Side effects}

Thirty four point three percent of patients noticed easier occurrence of a blue or purple coloration of the skin; $10 \%$ of people noticed gum bleeding, urinary and digestive tract bleeding; $60.5 \%$ of them took other anti-inflammatory medications/ /painkillers in the case of infections/arthralgia.

\section{Other medications}

Medications after PCI look as follows (Figs. 1,2): $5.4 \%$ of patients did not take regularly all recommended medications; $44 \%$ of patients happened to forget to take or ran out of some medications. It happened more often to people with lower level of education $(\mathrm{p}<0.001)$.

We also made the analysis of the presence of risk factors and patients knowledge about the depending on sex. The results are shown in Table 5 .

\section{Discussion}

The paper aimed at discussing the incidence of main risk factors for $\mathrm{CHD}$ in Polish patients after PCI.

Despite 50 years of clear evidence of the harms of tobacco smoking, it remains prevalent and constitutes one of the most important modifiable risk factors for premature mortality. Since the 
Table 5. Analysis based on sex.

\begin{tabular}{|c|c|c|c|}
\hline & Women (Yes) & Men (Yes) & $\mathbf{P}$ \\
\hline Current smoker & $15.2 \%$ & $24.7 \%$ & $<0.001$ \\
\hline Former smoker & $43.3 \%$ & $72.3 \%$ & $<0.001$ \\
\hline Smoking pack years & 22.27 & 16.04 & $<0.001$ \\
\hline Number of people who do not measure blood pressure & $12.4 \%$ & $24.5 \%$ & $<0.001$ \\
\hline $\begin{array}{l}\text { Do you think that the limitation of physical activity after successful } \\
\text { coronary angioplasty is advisable/beneficial? }\end{array}$ & $37.2 \%$ & $35 \%$ & 0.002 \\
\hline $\begin{array}{l}\text { Are you afraid of performing moderate physical activity } \\
\text { (walking, running, cycling, Nordic walking)? }\end{array}$ & $38.2 \%$ & $32 \%$ & 0.001 \\
\hline Do you expect weight loss after use of moderate physical exercise? & $68.3 \%$ & $69.3 \%$ & 0.137 \\
\hline $\begin{array}{l}\text { Do know which products have a positive effect on } \\
\text { the cardiovascular system? }\end{array}$ & $87.4 \%$ & $84.2 \%$ & $<0.001$ \\
\hline $\begin{array}{l}\text { Do you know which fats, bread, spices affect on } \\
\text { cardiovascular system? }\end{array}$ & $80.1 \%$ & $76.8 \%$ & $<0.001$ \\
\hline Do you eat regularly? & $67.3 \%$ & $59.3 \%$ & $<0.001$ \\
\hline $\begin{array}{l}\text { Do you think that drinking } 1-2 \text { cups of coffee daily has bad } \\
\text { influence on cardiovascular system? }\end{array}$ & $37.3 \%$ & $33.2 \%$ & $<0.001$ \\
\hline $\begin{array}{l}\text { Do you think that alcohol consumption has good influence } \\
\text { on cardiovascular system? }\end{array}$ & $26.2 \%$ & $34.7 \%$ & $<0.001$ \\
\hline $\begin{array}{l}\text { Have you been encouraged to alcohol consumption in either } \\
\text { treatment or prevention of diseases by your family or a doctor? }\end{array}$ & $25.9 \%$ & $32.6 \%$ & $<0.001$ \\
\hline $\begin{array}{l}\text { Have the dietary recommendations been helpful/have changed } \\
\text { your diet? }\end{array}$ & $74.4 \%$ & $71.9 \%$ & $<0.001$ \\
\hline Have you ever forgotten to take any medicament? & $43.2 \%$ & $48 \%$ & $<0.001$ \\
\hline
\end{tabular}

landmark 'Smoking and Health' report of 1962, it has been estimated that over 6 million people per year die as a result of smoking [7]. EuroBarometer survey, published in 2010, showed that the average smoking rate in the European Union countries amounted to 29\% [8]. According to EUROASPIRE III, there were, on average, $17.2 \%$ of smokers among patients with diagnosed CHD in 22 European countries [6]. Giving up smoking in patients with diagnosed CHD resulted in reducing the risk of death and myocardial infarction (MI) by $30 \%$ in the following 3 to 7 years [9]. The risk reduction probably results from reducing the activation of platelets, lowering the coronary artery contraction and the incidence of ventricular cardiac arrhythmias [10].

According to our report, $59.7 \%$ of patients who had undergone PCI used to smoke cigarettes. Despite having undergone PCI, $20.5 \%$ of patients continue to smoke. Men used to smoke more often. They also more often continued to smoke and have bigger number of pack-years. An alarming conclusion is that people who currently smoke are younger that non-smokers and that almost $60 \%$ of patients are exposed to cigarette smoke in their direct environment. People coming from small towns and big cities smoke equally often.

The physical inactivity may be responsible for up to $9 \%$ of all premature mortality worldwide and causes $6 \%$ of the total burden of disease from CHD [11]. The guidelines of the European Society of Cardiology indicate that post-coronary intervention patients should take moderate up to intensive aerobic activity $\geq 3$ times a week for $30 \mathrm{~min}$ [12]. Patients having sedentary lifestyle should be encouraged to start mild physical activity programs after stratification of risk connected with physical activity. According to the report, however, more than one third of patients (both men and women) believe that limiting physical activity after coronary intervention is beneficial. Similarly, more than one third of patients, more often women, are afraid of taking moderate physical activity. Such opinions are more often expressed by elderly people with lower level of education and living in smaller towns. It should be indicated that people with such opinions have higher BMI.

Increased serum concentrations of total cholesterol and low-density lipoprotein cholesterol (LDL-C) constitute main CHD risk factors. Hyper- 
triglicerydemia and small high-density lipoprotein cholesterol (HDL-C) concentrations are independent CHD risk factors. The World Health Organization estimates that about $8 \%$ of diseases in developed countries result from increased cholesterol concentration and almost $60 \%$ of CVD and about $40 \%$ of ischemic strokes in developed countries are caused by the total cholesterol concentration exceeding theoretical minimum $(3.8 \mathrm{mmol} / \mathrm{L})$ [13] Eighty-seven point four percent of patients had cholesterol and its fractions tested after the coronary intervention; $83.1 \%$ of people were informed what levels of lipids are correct. This more often refers to people coming from bigger cities $(p<0.001)$.

The American Heart Association indicated obesity as the main modifiable risk factor for CVD [14]. Diet is one of the most important modifiable risk factors for CVD. Dietary changes can help prevent CVD (primary prevention) and help to prevent the progression of the disease in people who already have symptoms or have been identified as being at high risk (secondary prevention) [15]. Special dietary recommendations (especially Mediterranean diet) proved to be beneficial in secondary prevention of CHD [16, 17]. Eighty-five percent of respondents declare to be aware of which products have a positive influence on the CVS and which ones can be harmful. These questions were positively answered more often by women, younger people, better educated, and coming from bigger cities. Unfortunately, more than $37 \%$ of people do not eat at regular times and $27 \%$ of people did not alter their diet based on the recommendations. The group not eating at regular times comprises men, younger people, lower educated, and with higher BMI. Women, younger people, better educated, and coming from bigger cities were easier to convince to change their dietary habits. Almost $35 \%$ of people, mostly women, believe that drinking 1-2 cups of coffee has a harmful impact on the CVS.

Numerous studies have proved that low to moderate intake of alcohol contributed to the reduction of mortality, mainly due to reducing the incidence of CHD. On the other hand, excessive drinking increased the risk of CHD and mortality [18-20]. Thirty-one percent of patients, more often men, believe that drinking alcohol has a beneficial impact on the CVS. The survey, however, did not specify the amount or type of alcohol and that is why the findings cannot be explicitly interpreted.

The INTERHEART survey estimates that $22 \%$ of MIs in Western Europe and 25\% in Central and Eastern Europe are caused by high values of $\mathrm{BP}$ and the patients with hypertension are at twice bigger risk of
MI than those who do not suffer from hypertension [2]. An alarming fact coming from our report is that $8 \%$ of patients after the coronary intervention do not control their BP even once a day. It more often refers to men, younger people with lower level of education and coming from smaller towns. Three percent of people, mainly coming from bigger cities, believe that in stressful situations it is acceptable to have BP values above 140/90 $\mathrm{mm} \mathrm{Hg}$, and 9\% declare that the correct pressure values mean such values which make them feel well. It is important to emphasize the fact that those people underwent PCI and they should know and understand the harmful impact of arterial hypertension and should essentially comply with the recommended maximum value of $140 / 90 \mathrm{~mm} \mathrm{Hg}$. It should be indicated that this is mainly elderly people, with lower level of education and coming from smaller towns that believe that the correct pressure values mean the values which make them feel well. Forty-one percent of patients declare that it is sometimes necessary during the treatment to take some additional medications due to high BP values. This means, at the same time, that such a huge number of post-coronary intervention patients have their BP controlled in the incorrect way and they need optimization, namely adding additional doses or increasing the doses they currently take.

Even the most successful coronary intervention in terms of technical aspect does not prevent restenosis in the stent. The deterioration of effort tolerance, recurrence of chest pains may constitute warning signals and the patients should be informed that such signals may appear and that it is essential to go and see a cardiologist. From $8 \%$ to $10 \%$ post-MI patients suffer from recurrent MI within 1 year after hospital discharge and posthospital discharge mortality remains higher than in the overall population [21].

An interesting finding is that more than one third of patients have chest pains and almost one third have difficulty climbing the second floor and $27 \%$ of patients have dyspnea. Particular attention should be given to the fact that $11 \%$ of patients have difficulty taking basic everyday activities. This refers more often to people with higher BMI and current smokers, and can result from inadequate rehabilitation of patients after PCI especially those having additional risk factors.

It often happens that the patients discontinue pharmacological treatment after acute coronary syndrome [22, 23]. In our survey, $90 \%$ of patients admitted to taking medications on a regular basis, $44 \%$ of patients, however, admitted that it had happened to them to forget to take or run out of 
a given medication. This more often refers to men and people with lower level of education.

\section{Limitations of the study}

A limitation of the survey was that patients were not divided into acute coronary syndrome patients and stable CHD ones. It was not specified what time after the coronary intervention the patients were included into the research. We can only confirm that in each case the patients were included during the first visit after PCI. Some questions asked to patients were too general the definition of a "healthy diet", for example, was not established and that is why it is not possible to analyze its particular elements. Additionally, the survey does not specify the amount of alcohol that could have a beneficial effect on CVS.

The advantage of our report is the fact that it includes a big number of patients of different levels of education and places of residence. The survey was carried out not only in academic facilities, as it is often the case in other countries, but also in small towns and villages. Therefore, our group includes all post-coronary intervention patients.

Despite its limitations, the research gives a reliable picture of the extent to which a patient understands the disease and of the cooperation between patient and doctor. An additional strength of the study was the fact that it was based on questionnaires, which makes it possible to assume that the patients did not have to face an embarrassing situation of admitting to a doctor that they did not comply with the recommendations.

\section{Conclusions}

To conclude, on the basis of the presented survey it is essential to implement to clinical practice educational programs for post-coronary intervention patients. These patients are at highest risk of having cardiovascular events. Based on our survey, educational programs should be addressed to all post-coronary intervention patients, especially to those coming from small towns. Improving educational programs in this group of patients should concern mainly secondary prevention - very good control of risk factors. It is very important to provide not only theoretical but also practical help such as in quitting smoking. Educational programs should give clear answer to patients' problems concerning everyday life. It is also important to emphasize the need for medication.

Conflict of interest: None declared

\section{References}

1. Nichols M, Townsend N, Scarborough P et al. European Cardiovascular Disease Statistics 2012: European Heart Network. Brussels and European Society of Cardiology, Sophia Antipolis, 2012.

2. Yusuf S, Hawken S, Ounpuu S et al. Effect of potentially modifiable risk factors associated with myocardial infarction in 52 countries (the INTERHEART study): case-control study. Lancet, 2004; 364: 937-952.

3. Clark AM, Hartling L, Vandermeer B et al. Meta-analysis: Secondary prevention programs for patients with coronary artery disease. Ann Intern Med, 2005; 143: 659-672.

4. Bjorck L, Rosengren A, Bennett K, Lappas G, Capewell S. Modelling the decreasing coronary heart disease mortality in Sweden between 1986 and 2002. Eur Heart J, 2009; 30: 1046-1056.

5. Palmieri L, Bennet K, Giampaoli S, Capewell S. Explaining the decrease in coronary heart disease mortality in Italy between 1980 and 2000. Am J Publ Health, 2010; 100: 684-692.

6. Kotseva K, Wood D, De Backer G et al. EUROASPIRE III: A survey on the lifestyle, risk factors and use of cardioprotective drug therapies in coronary patients from 22 European countries. Eur J Cardiovasc Prev Rehabil, 2009; 16: 121-137.

7. World Health Organization. WHO Report on the Global Tobacco Epidemic, 2011: Warning about the dangers of tobacco. WHO, Geneva 2011.

8. European Commission. Special Eurobarometer 332 'Tobacco'/ /Wave 72.3 - TNS Opinion \& Social. Brussels, Belgium 2010.

9. Cirtchley J, Capewell S. Smoking cessation for the secondary prevention of coronary heart disease. Cochrane Database Syst Rev, 2004; CD003041.

10. Goldenberg I, Jonas M, Tenanbaum A et al. Current smoking, smoking cessation, and the risk of sudden cardiac death in patients with coronary artery disease. Arch Intern Med, 2003; 163: 2301-2305.

11. Lee IM, Shiroma EJ, Lobelo F et al. Effect of physical inactivity on major non-communicable diseases worldwide: An analysis of burden of disease and life expectancy. Lancet, 2012; 380: 219-229.

12. European Guidelines on cardiovascular disease prevention in clinical practice (version 2012). Eur Heart J, 2012; 33: 1635-1701.

13. World Health Organization. The World Health Report 2002. Reducing Risks, Promoting Healthy Life. WHO, Geneva 2002.

14. Eckel RH, Krauss RM; AHA Nutrition committee. American Heart Association call to action: Obesity as a major risk factor for coronary heart disease. Circulation, 1998; 97: 2099-2100.

15. European Heart Network. Diet, Physical Activity and Cardiovascular Disease Prevention in Europe. European Heart Network, Brussels 2011.

16. Mente A, de Koning L, Shannon HS, Anand SS. A systematic review of the evidence supporting a casual link between dietery factors and coronary heart disease. Arch Intern Med, 2009; 169: 659-669.

17. Trichopoulos A, Bamia C, Trichopoulos D. Mediterranean diet and survival among patients with coronary heart disease in Greece. Arch Intern Med, 2005; 165: 929-935.

18. Dyer AR, Stamler J, Paul O et al. Alcohol, cardiovascular risk factors and mortality: The Chicago experience. Circulation, 1981; 64: 20-27.

19. Klatsky AL, Friedman GD, Siegelaub AB. Alcohol use and cardiovascular disease: The Kaiser Permanente experience. Circulation, 1981; 64: 32-41.

20. Power C, Rodgers B, Hope S. U-shaped relation for alcohol consumption and health in early adulthood and implications for mortality. Lancet, 1998; 352: 877.

21. Van de Warf F, Bax J, Betriu Z et al. Management of acute myocardial infarction in patients with persistent ST-segment elevation. Eur Heart J, 2008; 29: 2909-2945.

22. Eagle KA, Kline-Rogers E, Goodman SG et al. Adherence to evidence-based therapies after discharge for acute coronary syndromes: An ongoing prospective, observational study. Am J Med, 2004; 117: 130-132.

23. Ho PM, Spertus JA, Masoudi FA et al. Impact of medication therapy discontinuation on mortality after myocardial infarction. Arch Intern Med, 2006; 166: 1842-1847. 